International Journal of Advanced Studies in Humanities and Social Science (IJASHSS)

\title{
The Islamic Vigilantism: Dimensional Changes on International Power and Iranian Islamic Republic Prophecy
}

\author{
Behnam Sahranavard $^{* 1}$, Roghayyeh Hajhosseini2 \\ ${ }^{1} \mathrm{PhD}$ student in the field of international relations and a member of academic fellowship in \\ Ardebil teachers' University \\ ${ }^{2}$ An instructor of higher education center in Ardebil Province; Cellular \\ Corresponding Author E-mail: Sahranavard@Yahoo.Com
}

Received: 24 October 2018, Revised: 05 December 2018, Accepted: 20 December 2018

\begin{abstract}
The incident of Islamic Revolution in 1979 following by the fundamental changes in dimensional structure of international power may define primarily the great historical objects, which have appeared with Islamic Vigilantism at regional level. The revival stream of Islamic politics at present time, which has been affected by strong knowledge effects and under influence of Islamic Revolution, was practically and clearly manifested and exposed the major regional dependent systems fed by Islamic policy principles. Islamic vigilantism (awakening) is a part of illustration process and uprising among Islamic Community (Umma) that finally drives them to cultural, intellectual, and political independence. This study initially deals with interpretation of Islamic Revolution reflecting in national and international levels based on peaceful process and idealistic theories. Then dealing with subject of Islamic vigilantism as one of the external manifestations of Islamic Revolution this question will be addressed : What are some reasons and signs of dimensional change in international power and what is the Islamic Revolution prophecy (mission) in this regard? Afterwards, employing research documents, sources, and findings, we have deduced that in today's chaotic world, rather than modern reengineering on ideological, cultural, and religions issues and playing a positive and effective role in changing of international power equations, Islamic Republic should consider the regional and international requirements and contingencies with improving domestic potential. Further, through adaptation to the objectives, which were drawn by the existing tools, we may create a clear outlook in this regard.
\end{abstract}

Keywords: Islamic Revolution, Islamic Vigilantism, International Dimensional Power, Cultural Engineering (Constructivism). 


\section{Introduction}

One of the crucial sociopolitical events during the second half of twentieth century is Islamic Revolution of Iran (Barzegar, 2011). Like any other phenomena, incident of Islamic Revolution of Iran in 1979 has exerted several effects per se on its surroundings (Abbasi, 2012).

The end of Cold War and collapse of Berlin Wall, internal disintegration of Soviet Union and termination of bipolar system, extensive movements of the west surrounding Iranian environment, outbreak of Iraqi imposed war against Iran, Iraqi attack to Kuwait, the presence of American fleets in this region, changing traditional players in the region, emerging of new regional players, and several structural developments in political systems at countries and people's civil claims are some of these events.

Similarly, participation of Islamic Revolution in social climate of international relations have seriously influenced other players and the existing doctrines in international system (Abbasi: 2012: 138).

Inter alia, change of international government equations, particularly the structural power dimensional developments at Eastern Europe and especially internal disintegration of Soviet Union and many financial crises in Western Europe and USA reflect new signals of international power dimensional changes.

The incident of Islamic Revolution and formation of Islamic Republic of Iran has created a new cultural dialogue in which such a dialogue not only exited in Iranian nation but also a major part of Muslims suffering from passive mode and lack of self-sufficiency (Noorbakhsh, 2008).

The Islamic vigilantism (awakening) is considered as a great development within the environment of Islamic World which its special paramount role is summarized in its identity and this identity- seeking serves as the main term for transformation in the regional system. If tools have been the pivot of development in World First and Second Revolutions, Islamic Revolution and the existing climate may play a role in international relations regarding cultural, value- driven, and civilization- related issues in shifting the power and dimensional change of power equations. For this reason, AgentStructure Problem in International Relations Theory by Alexander Wendt and Postmodernist Constructivism (international relations) by Richard Ashley have become significant in definition of International Relations.

Moreover, today with developing knowledge and information at several cultural and social strata, the current communities have achieved knowledge and information at some level, which has criticized the existing order and governing management on them and now tended to take stride toward presentation and achieving a new system.

In geopolitical modern dimension of transformational era, social capital has been exposed to instrumental power of Western World and the dimensional confrontation of geopolitical modern dimension that formed versus hegemonic system shows that employing USA instrumental power may possess feigned nature in global administration (Resolution of Conference, 2012).

For this reason, in order to control the forces against hegemonic system, the USA is trying to disintegrate several resistant groups from each other and convert their internal differences into the conflict and opposition (Motaghi, 2012).

With pondering on outbreak of Islamic Revolution in 1979 and its reflection 
whether in terms of intra- and or extrastructural dimension and reaction of western system versus it, this study has referred to the reasons and signs of occurrence of development and change in international dimensional power. Further, through definition of Iranian status in these equations and its defects to extract the foremost perceptual and cognitive necessities and tools of changes in world dimensional power and to offer prophecy (mission) of Islamic Republic of Iran in transformation of the governing ideas over western dialogue, we will present a new model of governance (sovereignty) at the end of this article.

\section{Islamic Revolution and its impact on world power dimensional change}

Any great and important event may occur based on a certain theory in international relations (Dehghani, 2010) and/or it challenges the existing theories and doctrines and based on its own depth, it acts as creator of new theory. Constructivism (international relations) Theory is exposed to less challenge in recognizing the reason for assumed emerging role for values, ideas, and thoughts within the framework of nonphysical structures since within such a framework, it is possible to deal with emerging and determinant role of political Islam (Dehghani, 2010). According to this finding, government possesses a collective identity where this identity forms their fundamental objectives (Ghavam, 2008). From Alexander Wendt's view, realism, neorealism, and neoliberalism are materialistic and despite this fact that physical potential is important, it is possible to think more culturally about concept of structure (Moshirzadeh, 2010) while interactions of governments have not exclusively formed based on a series of fixed national interests (Ghavam, 2008).
Thus according to constructivism, Islam and Islamic values and standards (norms) form these movements and their interests and goals through creating Islamic identity and this is against secular identity and liberal values of nation- government on which the international system is based (Dehghani, 2008).

Islamic Revolution is against modernity in terms of cultural dimension of revolting against tradition (Naghibzadeh; 2002). It is a revolution that claims leadership of human communities against the crisisstricken west (Abbasi, 2012). Ghavam 2008) maintains that it is a great event in human's history and a big prologue so far something rising from its body (Davari Ardakani, 2011). More than anything else, this revolution presented an ethics- based approach and oppression- fighting culture with the framework of Islamic and revolutionary identity (Asariannejad, 2010).

Islamic Revolution could cause a discursive climate in which it includes micro- dialogues and rather than concept and intellectual reconstruction, it creates a modern culture, which is based on religious democracy, revival of Islamic thinking, world- orientation of Islamic Civilization, strengthening of modern social movements and arrogance- fighting (Dehshiri, 2007).

Essentially, one of the characteristics of great revolutions is that they challenge the power at two national and international levels (Sotoodeh, 2006) while emerging power in Iran is subjected to Islamic Revolution more than anything else leading to changing seriously the Iranian diplomatic course (Ramezani, 2009).

In modern political thinking, power has a fully physical and earthly essence. It refers to hegemonic status of modern human. Modern concept of power is intuitively 
self- additive and exploitive since it is defined as a trait out of characteristics of modern subjects and the will referent to devil soul (superego) and perfectly separated from pure context of spiritual ethics and justice (Monfared, 2012).

Alternately, power and software dialogues are considered as new concepts in political literature at international relations, which their recognition is important for further conception of governing relations on international system and this issue may justify the necessity of a terminology and epistemology concerning to power's software dialogue (Burton, 1967).

Michel Fuko argues that Islamic Revolution dialogue has been defined based on two dimensions: One is inside monarchical system that is called Pahlavism and the other is outside at the international arena i.e. western policy (Abbasi, 2012).

With incident of Islamic Revolution, transtraditional security dialogue achieved another reproduction based on Islamic ideological interpretation that assumed national borders to incorporate this trivial idea (Khalili, 2008). In contrary, its territorial and national domain has not substantially authenticity within Iranian geographical borders since this Islamic government possesses international, transnational, and overseas nature and essence, which is transiently and accidently benefitted from Iranian territorial and national basis to achieve Islamic favorable order and Islamic global community (Dehghani, 1997).

Today, the divine voice of Islamic Revolution in design of world political and cultural map has challenged equations and calculations of hegemonic powers (Salehi, 2012) and for this reason Islamic Republic of Iran tends to create a favorable community and to establish IranianIslamic civilization (Khoshchehreh, 2012) so that rather than reproduction of a new model of religious democracy- based government to create fundamental changes in outside world.

Likewise, the expanding climate of Islamictendency caused by outbreak of Islamic Revolution has led to numerous changes in world political structure (Abbasi, 2012) and it is followed by changes in roles, goals, and practical methods of governments in international system along with them (Roshandel, 2011) and even transforms role and performance of governments and it shakes the thinking basis and formation of government.

Although doctrine of engineering of developments and behaviors has existed in world scale and at level of interactions a long time ago, this idea has been emphasized after collapse of Soviet Union in the strategic studies so after occurrence of September 11 it acquired an appropriate opportunity to be presented and for fundamental development in strategic studies (Eftekhari, 2005).

However, according to author's view, these trends were dramatically changed following outbreak of Islamic Revolution and change in power equations in this region and type of ties between foreign powers and regional power structure (Eftekhari, 2005) and its effect has also penetrated into political structure of western world in addition to regional issues.

\section{Islamic vigilantism and dimensional change in world power}

No doubt, Islamic Revolution could enforce many effects in terms of intellectual, attitudinal, identification, and cultural bases at regional and global level. This revolution tends to establish a new and favorable order (Shiroodi, 2006). If we employ terms of security, politics, and strategy in their exact concepts, the start 
point of development in security system of any country is transformation of security doctrine in the given country (Khalili, 2008) and Islamic Revolution is the harbinger of creating new doctrine, which may claim for globalization rather than exertion of fundamental changes in structure of political pyramid of community and creating new dialogue out of sovereignty along with seeking for elimination of hegemonic system. It is a system, which on many occasions, tends to consider its evil act as righteous one, the oppression as justice, its colonialism as democracy, and non- humanistic and discriminative behaviors as human rights while on the other side epistemology of Islamic Revolution has been formed based on this idea that the world is divided into halves: one for the oppressed and the other for the arrogant or good and evil (Rahdar, 2007).

Alternately, the events which have occurred in the countries at North Africa and Middle East are some positive signs of influence caused by changes from Islamic Revolution. Middle East developments and uprising of Islamist movement in the region has caused a conceptual challenge which if we juxtapose it with vulnerability of regional and global political order and newly- emerging great powers then more dimensions of these transformations may appear (Ghodsi, 2012).

Islamic vigilantism (awakening) may be considered as a unique phenomenon and one of the distinct outcomes from Islamic Revolution in Iran which, compared to Islamic revival stream, is evaluated more perfectly and efficiently due to potential of its operational dimensions (Eftekhari, 2012:21).

Islamic vigilantism is a motivational and awareness status in Islamic community (Umma) (Mohammadalizadeh, 2012) that was suffering from sense of inferiority for several years. With Islamic vigilantism, the Muslims in Islamic nations set free (Fayaz, 2010) and it seems that domain of Islamic vigilantism to be more expanded increasingly.

This issue has some other impacts as well. With Islamic vigilantism and the realized developments in geopolitics of Middle East, we witness the substitution of common diplomacy instead of formal diplomacy and replacement of virtual social networks instead of formal media as well as management of perception and mind versus physical and bodily administration (Ghodsi, 2012).

Islamic vigilantism provides new dimensional power infrastructures. This is possible with creation of appropriate doctrines and theories in response to requirements of world community and with reliance on excellent, divine, and human thinking arisen from school of revelation and teachings of Mohammad's (PBUH) Pure Islam and renewable intellectual foundations, schools, and philosophy (Resolution of Conference, 2012).

\section{The reason for occurrence of change in world dimensional power}

All theorists in international relations have emphasized on this point that if the equilibrium is changed and any country tends to achieve extra strategic power, other nations and players may then resist against this measure. Resistance is not solely related to a certain geographical area. Resistance signs may be observed inside USA within the framework of movement against Wall Street to Europe and critical doctrines versus hegemonic strategy and in southwestern Asia (Identification of Islamic vigilantism).

The beds of emergence for such an event should be considered in attentive awareness and its following reactions in 
the field of recognition, impression, perception, and inference of nations in main pivots of administration of communities and deficiencies caused by management power, interests, and certain goals of hegemonic powers.

Although hegemonic system with money and militaristic and scientific power tries to control world system, its main problem is intellectual void of thinking that leads to advancement, growth, and development, which is aimed at humanity (Resolution of Conference, 2012). Western culture and civilization not only has not led the human to freedom and given them the taste of real freedom but also has made them extremely passive (Taghavi, 2006). Today what serves as important in the field of dimensional change at world relations, is the lack of balance and interaction between superior political players at national, regional, global, level and in international system. Quality of change before various and large global cultures is crucially important and cognitive and conceptual enriched sources in any school of thought may depict the legality and or prejudiced nature for each of them with reliance on rationalization and the governing principles on ideas of human community and drawing objective, ends, and trends.

Totality of cognitive schools in the field of power and a composition of implementation philosophy and its establishment at the world level may suggest that few schools may be embedded in pursuance to change levels, varieties and directions and allocate administration power and global generalization to their own.

According to world- oriented theorists, modern world communication systems are going to transform the relations between local physical situations and social conditions and they change geographical position of sociopolitical life. These affairs may be derived from certain times, places, and traditions through uprooting of identities (Hold, 2003).

On the other hand, Arnold Woofers defines the subject of world security within the framework of discursive thought and idea in western world. He maintains that security may be derived under some conditions that the dominant countries in global politics are not in challenging situation or they are not required to deal with war to remove the challenge. Such an approach means that Woofers and other theorists in western world have emphasized on a subject called influence and repute (Motaghi, 2012) and if conceptualization of influence and repute is measured as the concept of global legitimacy or subject of hegemony, sociological concepts will be preferably considered. Although global legitimacy may be disguised aesthetically with subject of democracy, hysteric crises in the west, disorders in change fields, way of west epistemological conflict and treatment and western cognitive schools with humans have contributed to these challenges and the field of power also signs of decline of world hegemony through proposing basic questions regarding quality of establishing hegemony and methods of its continuance have created some challenges both on western world and the nations called as Developing Countries.

\section{Signs of change in world dimensional power}

The incident of Islamic Revolution changed the course of regional strategies taken by two Superpowers and then led to some changes in their global strategies (Malakootian; 2006:260) followed by even creating some great challenges in the world (Fayaz, 2010). The paramount signs 
of change in world dimensional power may be sought for the following cases:

\section{Victory of Islamic Revolution}

Probably, one could search for starting point of essential transformations at international relations in the case of Islamic Revolution. Hoisting Islamic flag as a solving agent for the problems, Islamic Revolution could initiate the struggle against corrupting governments with indirect revival of new generation from Islamic movements (Bazrafkan, 2012). The transnational nature of Islamic Revolution is Iran's international status and strategic importance of Persian Gulf and Middle East that signifies Iranian revolution is an international event and phenomenon (Dehghani, 2010). As the first link of religious ideological ideal with Islamic system, government, and community, Islamic Revolution should take great strides in the course of Islamic community (Umma). If we consider occurrence of Islamic Revolution as the starting point of a historical great development so this revolution may be considered as foundation of the pyramid at world power dimensional change.

\section{Fall of American repute as world hegemony}

Hegemony means an inter-communal system in which the dominant member i.e. hegemony as well includes both ambition and power for controlling policy and external actions of other members to maintain structural form and functional relations in the system based on concepts, requirements, and goals (Amirahmadi, 1989). Gilpin believes in three conditions in formation of hegemonic stability (Gilpin, 1987): The presence of a hegemonic power, ideological commitment to the governing ideology and common interests between members.
But these challenges have been tarnished and discounting parameters are agreed in the USA, i.e. declining dollar status, reduced foreign exchange balance, extremely dependence on direct foreign investment, reduced looking outside in Americans' foreign investments, and new economic crisis 2008 (Saee, 2010). Vietnamese War costs, extended militaristic aids to the allied nations, formation of European Union, role of multinational enterprises, reduced dominance of the USA on oil market, and outbreak of crisis 1973 (Saee, 2010) are some of the reasons for decline of USA's decline, which have been exposed to signs of other reactions by members in modern dimensional geopolitics. Similarly, the emergence of modern tools and financial institutions, and collapse of international exchange rate fixed system can be considered as other symptoms of this decline (Khoor, 2004). In contrast, fall of American world power has exposed the USA to these movements more than ever in rising power of independence- seeking movements in Third World Nations (Amirahmadi, 1989).

Even some experts argue that two theories of New World Order and Clash of Civilization have basically designed for this purpose (Emami, 25, 28). The role the USA plays as an international police and arbiter in controlling radical countries which opposed to existing situation in Persian Gulf and its exposure to some risks like German Militarism, Russian Bear, Chinese Dragon, and Islamic Land has caused the world Superpower to count on them wholly and entirely (Emami, 2003).

\section{European events and their ambiguous future}

European Continent has witnessed many events after the end of World War II. Dichotomy of this continent into eastern 
and western blocks, conflict in Cold War during bipolar period, alliance of two Eastern and Western Germany, everincreasing fall of UK power, establishing new countries in eastern part of this continent and at recent time environmental issues, terrorism, conceptual and cultural crises were some of those events that turned into serious problems to be resolved in this Green Continent with establishing European Union (EU) but cultural and political disconformities of European countries and especially economic various structure and long distance between those economic system in terms of economic parameters such as social welfare, life expectancy, insurance, and income per capita have caused this continent to suffer from a great deal of financial crisis.

\section{Islamic Vigilantism (Awakening)}

Islamic vigilantism is a term to express a movement based on awareness of Islamic liberator principles, political practice, and measures to change status quo in order to achieve appropriate condition based on Islam- seeking as well as importance of the element of religious task rather than surrounding ephemeral interests (Eftekhari, 2012). Identity and vigilantism based on Islam is a sign of change in world dimensional power in the future (Rahbari and Ettelaat, 2012). Despite varieties of tendencies and different subsystems, Islamic vigilantism may convey the single message to history i.e. the sense of selfconsciousness of Islamic Umma (community) and deciding to refer to Islamic pure and righteous values (Bahrami, 2012).

Islamic vigilantism has threatened the sovereign states in Arab world and challenged political legitimacy of their rulers so this signifies the point that Jihad (campaign) in the course of ideological ideals exiting from restraint suffocating conditions have been turned into a dominant thought in Islamic world (Ramezani, 2012).

\section{Iran's status in fundamental change in world dimension}

According to many scholars, revival of religion and returning spirituality to the contemporary world are indebted to Islamic Revolution (Barzegar, 2011) and the rising role of Iran is referred to as two elements of power namely geopolitical identity and Shiite element more than anything else (Ghodsi, 2012).

This country is located on a starting point upon the outset of drawing change in world dimensional power and it may enjoy special status in fundamental change in world dimension:

\section{Establishment of first Islamic System}

Islamic Republic of Iran is the first country, in which a religious democratic system was established, negating two schools of capitalism and communism and dictatorship and monarchical systems, while it acquires its legitimacy from Islam, as the foremost attribute and consolidating element of this Islamic system (Dehghani, 2007).

\section{Ideological nature of system}

Given that Islamic Republic has emerged and realized from Islamic Revolution within the Iranian territorial domain (Dehghani, 2001) so the fundamental structure of this system, which is based on religious conceptual values and norms in legal structure of system under title of Constitution, has been manifested in this sense.

\section{Dynamism of religious conception with respect to its bases}


The fertility and sterile nature of the west in exogenesis of novel thoughts and philosophy, which have been born and derived from western humanism, and at opposite point, the exiting dynamic and all-over generative religion of Islam that includes some injunctions, prayers, and ethics for life and death of all creatures and universe, may be deemed as a heavy scale for benchmarking two western materialist thoughts with Islamic religion.

\section{Iranian territorial situation}

With respect to location of Iran in the core of earth, which has been called as heartland and serves as east-to-west corridor and north-to-south hub and enjoys geopolitical, geohydropolitical, geoideologist, and geocultural position, it may act as enormous potential and capacity in occurrence and formation of modern world dimension.

Similarly, several huge subterranean deposits and sources, especially oil and gas, along with other divinely resources and bounties may be considered as some other positive points in outweighed position of Iran in world ties. However, with respect to creating the newly founded infrastructures, occurrence of Imposed War, ideological issues, and domestic barriers, Iran suffers from some defects in change of world dimensional power as well.

Modernism and cultural passivity, selfconstructed eclecticism, cultural blind mind syndrome, poverty in social modeling, lack of macro- level engineering (Razenahan; 2007:92), ignorance in type and quality of world power, poor diplomatic system, vacuity for lack of national innovation system, lack of growth and development of conceptual and linguistic characteristics of human related teachings and sciences, and their relevant fields in Iran (Mohsenianzadeh, 2010), and poor ontology in humanities are some of these barriers and defects.

\section{Necessity of modern cultural reengineering in world dimensional power}

Cultural engineering (constructivism) in the western land has been engineered oriented and instrumental rationalism so according to this rationality, soft and hard products are made. Given that such rationality does not enjoy the broad-based and global reputation for manufacturing of soft products, the major part of produced soft knowledge, which essentially serves as value- driven theme especially of basic and fundamental value types, possesses a very limited cultural range (Razenahan, 2007).

Eric Ferrum, the American distinguished psychologist and sociologist, refers to removing human's vacancy and his/ her humanistic and personal relations and as a result of conversion of today human into the reactive and passive individual through interpretation of pathogenic syndromes of technology and technological society on human at the present time (Taghavi, 2006).

Failure of positivist theories in predicting and analyzing changes put the attention to cultural and social factors high on the agenda for cultural theorists and sociologists where emergence and developing of constructivism or social creation are in fact the products of this condition (Ghfari, 2008).

With respect to the fact that cultural life for any generation is seemingly affected by thinking and ideas of parameters at the given period (Kazemi, 2003), the field of training- cultural studies should improve their capacities and potentials in the field of theorization and hypothesizing from sociological perspective to display more 
horizons and adaptation to the reality (Bagheri, 2005).

Likewise, with respect to stratification of cultural levels as well as necessity for spiral movement to achieve cultural engineering, a conceptual model of collage strategy may be taken. This metaphor is typically borrowed from view of postmodernist artists, which has linked the mystery of stability and sustainability of antecedents' art to modern creative rhetoric and innovation and purposed some tables in which tradition and modernity are composed together (Mohsenianzadeh, 2005).

Occurrence and victory of Islamic Revolution has challenged western organization model in general, and cultural engineering within nations and at world arena in particular, per se (Eivazi, 2004).

As a theoretical strategy, it should be implied that philosophy of social relations in definition of Iranian local conditions and Muslim nations and lands should clarify its essential analytical basis to expressing the relationship among God and human's essence and the humans' collective relations with others, their contracts and each of quality of production, and reproduction together (Bagheri, 2007).

The basic performance of cultural engineering of the country comprises identifying and establishing the effective proportion and balance between instrumental, relative, contingent, substantial, authentic, and absolute values by creating structural and content- related integration and unity in the culture at this country $(2007,95)$.

In fact, the model of global strategic engineering based on Islamic principles, unlike hegemonic bases taken by the west by the leadership of the USA, is more consistent with idea and thought of Imam Khomeini (RA) (Eftekhari, 2005).
In the course of reviving religious knowledge and in addition to challenging conceptual bases and principles in modern world, Muslim thinkers should be also responsive to several critiques and challenges that have been purposed by western thinkers and scholars as opposed to religious bases and sciences conception (Parsania, 2008).

Therefore, in the field of modern cultural engineering, Islamic Republic of Iran should make efforts to enhance spiritual and moral excellence of community through providing cultural healthy platform and climate (Article 3 of Constitution) and acceleration of socioeconomic development of the country by creating acculturation and adaptation to the local culture (Razenahan, 2007). Further, rather than implementing cultural vaccination in the country and drawing appropriate cultural lines proportional to social climate of the nation, it should be able to resist against the flooding of cultural and media attacks by clear responsiveness and producing cultural valuable and outweighed products. Above all by creating aesthetic, audiovisual, and media attractions, it could acquire a weighted share in world cultural dialogue and introduce modern products via adoption modern cultural reengineering so that it draws attention in global relationships and makes traditional concepts and literature significant by new concepts in world dimensional power range.

\section{The strategy of Islamic Republic of Iran in the change of world dimensional power}

The nations welcome the schools and approaches that can present the logic and interpretation of change and or the relevant requirements for this change along with empirical and prospective 
reasoning, draw national and international life risks and bottlenecks for the nations in this historical event and also provide intellectual and mental attraction and satisfaction for the nations and prepare the ground and activate it for them.

Similarly, cognitive commonality of schools in five fields, i.e. Human, satisfaction, information and knowledge, benevolence, and accountability, may compose five cornerstones of justice, ethics, peace, freedom, and oppressionfighting and symbiosis with ontological desires in world political conception. The most key prosperous and advantageous level of schools in cognitive and conceptual arrangement of global levels is introducing conceptual layers, production, and development of consensus at global layers, which oriented various and plural world identities toward original applications and assayed the integration voice for change. Thus, with respect to quality of changing, the position of players within dimension of internal factors including hardware factors such as energy, industry, and communication devices, and software agents like philosophical rational highflying and development level and also external factors consisting of software agents such as militaristic- political structure of units, technological economic structure of units, and communication position of software agents including political structure of international order, international legal institutions, international unions and organizations, and the regulations, which arose from international requirements (necessities), based on which the Islamic Republic of Iran should be able to play an essential role in changing world dimensional power by taking appropriate environmental and international strategies. Among of them, it necessitates taking the following points into consideration:

1- Realistically recognizing the endogenous conceptual bases of Iranian- Islamic thought-; progress and otology, and thoughtful critique of power philosophy in the west and power philosophy in the contemporary world;

2- Possessing divinely integrated thinking fundamentals and human allinclusive growth and development with taking approach toward Islamic vigilantism;

3- Reconstruction of modern knowledge and rereading of religious sciences, paying attention to cultural identity of modern knowledge may provide the possibility for a reverse movement and it is the reconstruction of scientific conception based on bases and principles and or religious metaphysics. This approach, instead of reference and revision of western theory, deals with rereading Islamic knowledge and culture and deep layers of this knowledge thereby modern scientific conception is to be reconstructed in a structural transformation (Parsania, 2008).

4- Creating knowledge and innovation maze (Hamidizadeh, 2008) and four modes of knowledge conversion from sociability and moving from tacit knowledge toward another implicit knowledge; and extroversion and moving from tacit knowledge toward explicit knowledge; composition and moving from explicit and clear knowledge toward another explicit knowledge; and introversion and moving from clear to explicit knowledge.

5- The necessity of recognition and definition of Iranian scientific model again (Ziba Kalam, 2011): Focus on 
beneficent sciences is the first step in semiotics of philosophy of knowledge from Islamic view. A relentless effort should be started through producing useful knowledge and smart automation in scientific priorities and preparation of prosperous scientific maps through cooperation with freedom- lovers and divinely scholars in the world in order to employ knowledge and technology as the main factor for producing wealth and to increase share of knowledge, experience, and innovation with cooperation with scholastic communities.

6- Activation of interpreter agents including intellectuals and elites (Mohammadalizadeh, 2012).
7- Exploiting experiences and preventing repeated domination of colonialism (Mohammadalizadeh, 2012).

8- Active communication with other countries and consolidation of friendship link (Negahdari; 2008).

9- Developing fundamental research (Siahposh, 2011)

10-Creating Islamic global unity based on religion, ethics, and knowledge (Naser; 2012)

11-Justly refinement of surplus claims

12-Renovation of socioeconomic structure of the country

13-Empowerment of humans

14-Rising efficiency and economic growth and moving in the course of Development Plans within a certain cycle.

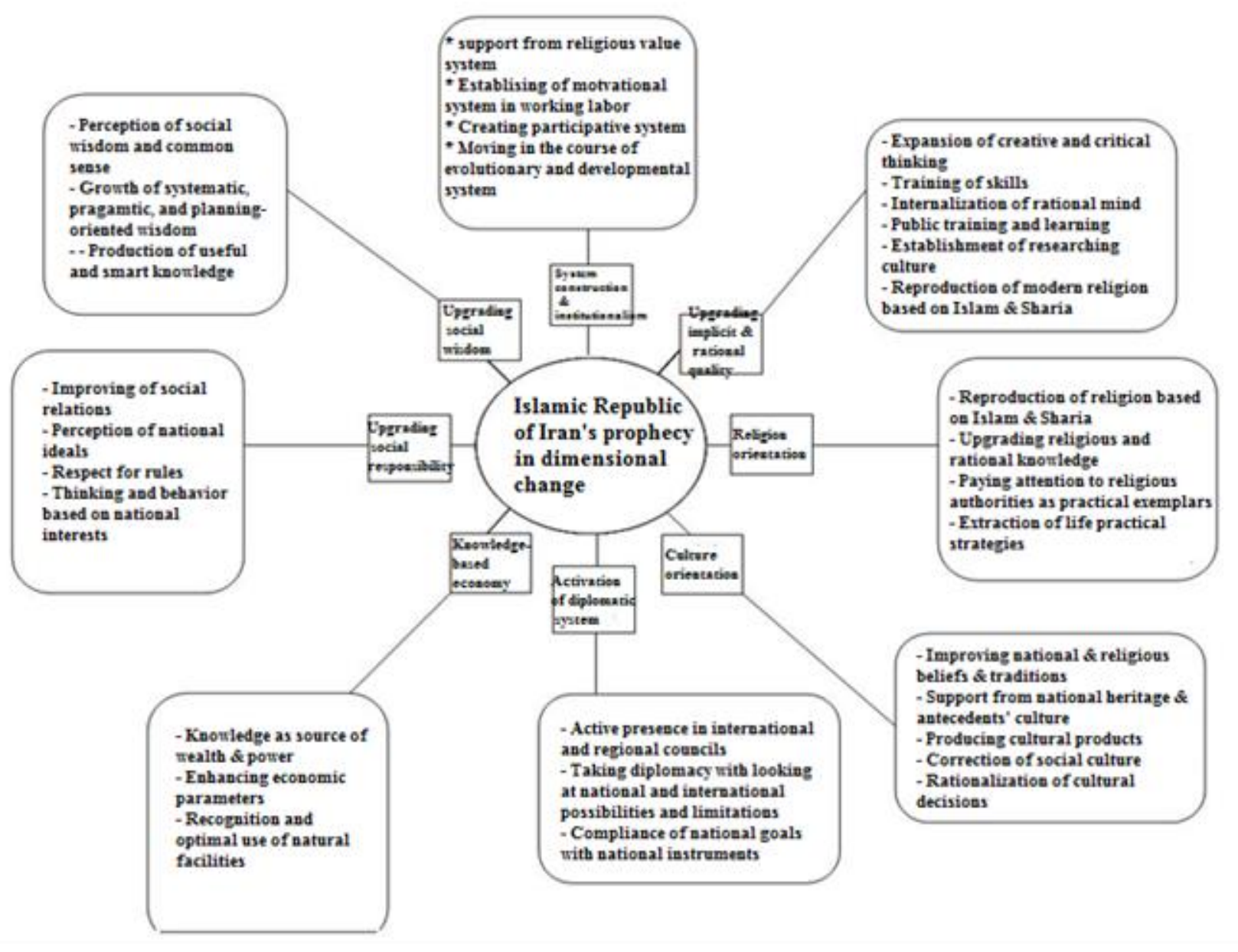




\section{Conclusion}

The event of Islamic Revolution and its consequence has been followed by outstanding change at regional and international levels. The occurrence of some other numerous changes during 1980s and 1990s has caused a great historical event to initiate. And Islamic vigilantism is an important sign of change in world dimensional power and in comparison to sociopolitical conditions and circumstances in Islamic Nations with their status before the Islamic Revolution, it signifies an obvious change in most of them (Malakootian, 2006).

In the clear and hidden competitions to determine new queuing within international system, the important point is to form a type of strategic vigilantism in global opposition to world hegemony and authoritative measures made by USA (Reshno, 2011).

There is no doubt that power equilibrium and structure in the Islamic- Arabic areas and northern Africa is in such a way that rather than inter-field widespread effects, any structural change and development in this region will cause several modern geopolitical and geostrategic tremors there (Reshno, 2011).

Among them, any strategic planning and or thoughts made by international powers are aimed at public developments and uprising that have been done regarding basic developments and changes within some concepts such as traditional geopolitics into neo-geopolitics or modern geopolitics (Reshno, 2011).

Under such conditions, nation's awareness and recognition of their own properties and potentials as well as taking scientific and comprehensive strategies for upgrading global status and achieving prosperity and development are some of paramount requirements (Pasandideh, 2007).
Alternately, Islamic Revolution is a superior challenge against duration of the epistemology of eastern knowledge (Rahdar, 2007). The revolution which its theme is Islam and at the same time Islamic religion with its teachings, moral philosophy and rites may drive Muslims towards stronger networks based on principle of brotherhood and fraternity and act as appropriate platform for generating of human, social, and spiritual capital (Rohani Saraf, 2008). This enormous potential is one of the foremost concerns for statesmen in western systems and one of the issues, which have been preoccupied in the USA especially since $90 \mathrm{~s}$, is Islamist wave in the region (Emami, 2003).

Although Joseph Nye argues that the paramount concerns of the USA in modern world are not related to a certain enemy, attrition of stabilized foundations in traditional order that USA has founded is observable (Ghodsi, 2011). On the other hand, he called modern world dimensional changes as soft power. According to Joseph Nye, soft power is the ability of achieving something, which we intend to acquire with attracting and satisfying others to realized our objectives. This type of power differs from hard power since it is cheaper and more practical than coercive force and compelling (Nye, 2004).

In any case, several distinctive signs are seen since the beginning the great historical turning point during three past decades and Islamic vigilantism is one of the last components of world dimensional power, which could be considered as a theoretical basis for public uprising and revolts due to sense of contempt in these nations within their own suffocating political system and dependence of these systems to hegemonic system so that along the Islamic epistemological and identityrelated statement they may cause 
continuous tremors in rulers' palaces in these countries and propose many alarming messages for orientations of western system.

In this critical course of time, in order to play crucial role, Islamic Republic of Iran requires adapting its goals to the exiting tools so that with taking realistic approach toward realized developments and considering its own properties, it could act as leveling machine for public claims of these countries in the uneven labyrinth path. Inter alia, the prior and subsequent values are necessary for this validity. In terms of internal example, policy is required to stablish security and individual welfare at highest level in the society and also as an outside example, it should tend to acquire such objectives relying on idealistic and realistic ideals in this way.

That said, to achieve internal and external objectives, a certain strategy and tactic should be taken and the long-range strategy of Islamic republic should be changing of world dimensional power in favor of its own and Islamic world. Although it is probable that these strategies and tactics are not apparently aligned with each other, the outcome should be thought on .

It is the strategy, which could facilitate the highest level of cultural and social interaction and exchange between communities and encourage Islamic nations to achieve harmonically and congruently justice, peace, freedom, morality, and symbiosis while being committed to its principles, processes, and products. One may be hopeful to most fluctuating changes and effectiveness in world dimensional power under such condition.

\section{Sources and References}

Eftekhari A. (2012). "Islamic awakening in theory and practice", Tehran University of Imam Sadegh (PBUH).

Amirahmadi H. (1989). The role of coercion in creating regional hegemony in the changing world", a collection of essays from seminar on exploring issues relating Persian Gulf.

Emami M. (2003). "The foreign effective factors on Persian Gulf", Tehran: Political and international studies office.

Ettelaat (newspaper), Tuesday August $14^{\text {th }} 2012$, No. 2231.

Asadian A. (2012). Developments in powers division (an attitude to engineering changes in political power)", Tehran: Majd Pub.

Elahi H. (1989)."Persian Gulf and its issues”, Tehran: Ghomes Press.

Imani Satvat A. (2008). "The cultural bases of scientific authority in Iran", Journal of strategic attitude, vols. 97-98, Jan \& Feb 2009.

Eftekhari A. (2005). "The course of developing strategic studies; global trends and Iranian experience", a collection of essays purposed in National Conference on Strategic Studies in IRI, Tehran: Strategic studies research center.

Bazrafkan M, Javdani Moghadam M. (2012). Islamic awakening and movements in Middle east", a collection of essays in book of Islamic awakening in theory and practice; Tehran: University of Imam Sadegh.

Bagheri S. (2007). "The presentation of a model for change engineering of religious orientations in Iran", a collection of essays purposed in the $1^{\text {st }}$ National Conference on 
Cultural Engineering; Tehran: Ministry of Culture and Islamic Guidance, vol. 2.

Barzegar E., Khani Arani E. (2011). "Islamic Revolution of Iran's reflection on Western Europe", quarterly of Islamic Revolution studies, vol. 26, fall 2011.

Resolution of Conference on "Strategic Role of universities and religious seminaries in change of world dimensional power", National Defense Higher University, 2011.

Barzegar K., "Arabic development and power equilibrium in the Middle East".

Bahrami B., \& Kazemi M. (2012). “The study on cognitive concept of Islamic Awakening and its elements", a collection of essays purposed in International Summit of University Professors \& Islamic Awakening; Tehran: Secretariat of International Islamic Awakening Council.

Parsania H. (1987). "Reconstruction of modern knowledge and revision of religious science", quarterly of culture leader, vol. 3, fall 1987.

Pasandideh M.M. (2007). “Engineering of national culture in millennium of knowledge", a collection of articles purposed in the $1^{\text {st }}$ Conference on Cultural Engineering, Tehran: Ministry of Culture \& Islamic Guidance, Vol.3.

Taghavi S.R. (2006). "Cultural implications", Tehran: Nakhil Pub.

Hamidizadeh M. (2008). "The reengineering strategies in $R \& D$ centers for knowledge creation", Journal of strategic attitude, vols. 97-98, Jan \& Feb 2009.

Hassanzadeh M. (2011). "The presentation of a comprehensive cognitive method for surveying knowledge strategic areas in IRI at outlook of 2025", quarterly of second scene, vol. 13-14, spring \& summer 2011.
Khalili R. (2008). Definition of IRI security development", quarterly of strategic studies, vol.40, summer 2008.

Khoor M. (2004).“Globalization and south”, Transl. Saee Ahmad, Tehran: Ghomes Press.

Khoshchehreh M., Habibi N. (2012). "The basic principles and key elements on Islamic Iranian model for advancement I terms of upstream documents of the system", quarterly of strategy, vol. 62, spring 2012.

Dehghani S.J. (2007). "Dialogue of Justicecentered fundamentalism in diplomacy of Ahmadinejad's Cabinet", two quarterlies of political science, vol. 5, spring \& summer 2007.

Dehghani S.J. (2010). "The impact of Iranian Islamic Revolution on theories of international relations", quarterly of Islamic Revolution, vol. 20, spring 2010.

Dehshiri M. (2007). “Cultural effects of Iranian Islamic Revolution on international relations", quarterly of Islamic Revolution, vol. 13.

Daheshyar H. (2002). "USA foreign policy and hegemony", Tehran: Publication of Third Line.

Davari Ardakani R (2012). "Islamic Revolution and world status quo", monthly of public culture, vol. 7, Feb 2012.

Ramezani R. (2009). “Conception of Iranian foreign policy", quarterly of foreign relations, Vol. 1, spring 2009.

Ramezani M. (2012). “Islamic awakening from viewpoint of Seyed Qotb and Hamed Abu Zeid", a collection of essays in International Summit of University Professors \& Islamic Awakening, Tehran: International Islamic Awakening Council. 
Razenahan F., Nazemi Ardakani M. (2007). "Cultural engineering and country's cultural map", a collection of articles purposed in the $1^{\text {st }}$ Conference on Cultural Engineering; Tehran: Ministry of Culture and Islamic Guidance.

Reshno N. (2011). "Islamic awakening from geopolitical perspective", Tabnak website, Sep 17th 2011.

Khorasan Newspaper, dated 12/18/2012, vol. 18295.

Rahdar A. (2007). "Islamic Revolution as founder of discursive hegemony of the west", Quarterly of Islamic Revolution Studies, vol. 8, spring 2007.

Rohani Saraf Vazvani M. (2008). "Islamic religious values and social capital", a collection of articles in Conference on Social Capital and Development in Iran; Tehran: Publication of humanities studies and development.

Roshandel J. (2011). "National security and international system", Tehran: SAMT Press.

Ziba Kalam S. (2011). "The necessity of recognition and redefinition of Iranian scientific model", a collection of articles in the scientific conference on a prologue to workbook of Islamic Republic System, vol. 2; Tehran: Tehran University.

Saee A. "An exploration into theoretical perspectives toward international geopolitics", quarterly of political studies.

Saee A. (2009). "The critique and evaluation of international system: pros \& cons", quarterly of political studies, vol. 5, fall 2009.

Siahposh S.A. (2010-11). "The features of Civilization- Builder University", two quarterlies of cultural research community, vol. 2, fall and winter 2010 .
Sotoodeh M. (2006). "Islamic Republic of Iran and international relations", a collection of essays purposed in Conference on Islamic Revolution, vol. 2, Qom: Maaref Press.

Shiroodi M. (2006). "Islamic Revolution, International system and globalization", a collection of essays purposed in Conference on Islamic Revolution, vol. 2, 2006.

Salehi J., \& Shahabi M. (2012). "The effects of Islamic Revolution in Iran on Islamic awakening in the region of Middle East", quarterly of Islamic awakening studies, vol. 1, spring 2012.

Abbasi Ashlaghi M. (2012). "Conceptoriented reflections of Islamic Revolution in Iran on Islamism in Middle East", quarterly of strategy, vol. 62, spring 2012.

Asariannejad Hossein (?), "An outlook to discursive structures of change in world dimensional power in Imam Khomeini's school"

Asariannejad H. (2010). "Cultural strategies and authoritative government", National Defense Higher University, DAA Pub (2010).

Asariannejad H., \& Alavi S.M. (2010). "The culture of waiting and strategy of preparation for appearance (of twelfth Imam)", research newsletter of strategic sciences.

Ghafari M., Shariati S. (2008).“Foundations of idealisms in Iranians' political culture", quarterly of cultural strategy, vol.3, fall 2008.

Fayaz E. (2010)."Engineering of public culture", Tehran: Nashr-E-No.

Ghavam A. (2011). "Theory of international relations", Tehran: Ghomes Pub. 
Ghavam A.A., Zargar A. (2010). "Building of government, building of nation and theory of international relations", Tehran: Asar Nafis Pub.

Ghavam A.A. (2005). "Constructivism: Synthesis of positivism and post-positivism", quarterly of law and politics, vol. 2, spring 2005.

Gheisari N., \& Ghorbi S.M.J. (2012). "The review on software dimension of power and psychological operation phenomenon", Journal of culture engineering, vols. 65-66, June-July 2012.

Ghadami A. (2012). Middle East geopolitical developments and diversity of strategies", quarterly of Islamic awakening studies, vol. 1, spring 2012.

Kazemi A.A. (2003)."Modernism crisis and political culture in contemporary Iran", Tehran: Ghomes Pub.

Moshirzadeh H. (2010). "The change in theories of international relations", Tehran: SAMT Press.

Malakootian M. (2006). "Regional and international impacts of Islamic Revolution", a collection of articles from Islamic Revolution Conference, Qom: Maaref Press, vol. 2, 2006.

A series of essays in the $1^{\text {st }}$ National Conference on Cultural Engineering; Tehran: Ministry of Culture \& Islamic Guidance, 2002, 5 Volumes.

Mohsenianzadeh M. (2010). "The presentation of strategic cultural engineering conceptual model with Collage approach", journal of local strategy, vol. 105, June-July 2010.

Naser Hesam (2012). "Creation of global unification based on religion, wisdom, ethics, and knowledge", a collection of essays in International Summit of University Professors and Islamic Awakening, Tehran: Secretariat of Islamic Awakening International Council.

Negahdari B. (2007). "The prologue on strategic planning of cultural development", Tehran: Omid Amjad Press.

Mohammadalizadeh A., Motaghi E. (2012). "The major components of Iranian foreign policy in light of Hazrat Imam Khomeini's Discourse of Islamic Awakening", A collection of essays in International Summit of University Professors and Islamic Awakening, 2012.

Motaghi E. (2012)."The study on power system from modern geopolitical dimension", 2012.

Monfared S. (2012). "The brief look at characteristics of modern human sciences", monthly of public culture, vol. 9, May 2012.

Noorbakhsh S.Y., Soltanian S. (2011).“The impact of Islamic Revolution on cultural dialogue of Muslims in the world", a series of articles purposed in the $1^{\text {st }}$ Scientific Conference on prologue to workbook of Islamic Republic System, Tehran: Publication of Tehran University, vol. 1, 2011.

Naghibzadeh A. (2002). "The effect of national culture on IRI foreign policy", Tehran: Political and International Studies Office, 2002.

Nooraee M. (2010). "Variability of community", two quarterlies of Community of Cultural Inquiry, vol. 1, spring \& summer 2010.

Hold David \& McGraw, Anthony (2003). "Globalization and its opponents", Transl. Erfan Sabeti; Tehran: Ghoghnoos Press, 2003. 
Hamshahri (newspaper), dated February $26^{\text {th }} 2013$, no. 5919.

Keohane R. (1981). "After hegemony: Cooperation and discord in world political economy", University Press.

Gilpin R. (1967). "The political relation", Princeton University Press.

How to cite this article: Behnam Sahranavard, Roghayyeh Hajhosseini, The Islamic Vigilantism: Dimensional Changes on International Power and Iranian Islamic Republic Prophecy. International Journal of Advanced Studies in Humanities and Social Science, 2019, 8(4), 332-349. http://www.ijashss.com/article_84382.html 